\title{
Social Dialogue: A Tool of Social Reintegration and Post-Conflict Peacebuilding in Nepal
}

\author{
Chiranjibi Bhandari
}

\begin{abstract}
Successfully reintegrating former rebels into civil society is a crucial task in postconflict countries. In the aftermath of a decade-long conflict (1996-2006) in Nepal, management of arms and armies became a major issue in the domain of post-conflict peacebuilding. "From Combatants to Peacemakers" was an initiative to promote peace and harmony among the former ex-combatants and host communities. In this context, this article highlights the role of social dialogue, which proved effective in promoting social harmony, peace, and reconciliation among ex-combatants and community members in Nepal. Also, the article explicates the worth of social dialogue that may be used in other parts of the world to successfully reconcile former antagonist groups into the same communities.
\end{abstract}

Keywords dialogue, ex-combatants, reintegration, peace, Nepal

\section{Context}

The Comprehensive Peace Accord of November 2006 marked the end of a decade-long conflict and led to political transition in Nepal (United Nations Peacemaker 2006). The agreement succeeded in receiving the approval for the state to administer the rebel army and seize weapons from the insurgents. Out of many other issues in post-conflict peacebuilding, the integration of insurgents into civilian life or into the national army, or facilitating voluntary retirement and reintegration, remained a socio-politically and technically challenging issue in Nepal. During the period of conflict (1996-2006), more than 13,000 people were killed, more than 1,000 people disappeared, and hundreds of thousands were displaced (Bhandari 2015, 63; NIPS 2013; Joshi and Pyakurel 2018). Following the 2006 Comprehensive Peace Agreement, the Maoist Army combatants were stationed in cantonments until a further political agreement could be reached to determine the terms of their release (Simon, Bhandari, and ex- PLA research group 2015; Bhandari 2017). The Maoist army combatants were stationed in 
seven main and twenty-one satellite cantonments, and, as part of its assistance in the peacebuilding process, the United Nations Mission in Nepal (UNMIN) verified about 19,602 people as former combatants and categorized 4,008 as verified minor late recruits in 2007 (UNDP Nepal 2011).

Since the verification of combatants by UNMIN, the future of the Maoist Army combatants in the cantonments was one of the key issues of debate among political parties and in the Special Committee. The committee was a cross-party constitutional mechanism which was formed in accordance to the provisions mentioned in Article 146 of Interim Constitution of Nepal 2007 that states "the council of ministers shall form a special committee to supervise, integrate and rehabilitate the combatants of the Maoist Army, and the functions, duties and powers of the committee shall be as determined by the council of ministers" (UNDP Nepal 2009).

This topic was highly contested and no resolution was reached until November 15, 2011 when the major contentions concerning the former combatants were outlined to include the issues of integration into the Nepali Army, handover of Maoists armaments, and the mode of reintegration and rehabilitation of ex-combatants (Subedi 2013; Bhandari 2017).

In 2012 and 2013, the cantonments were finally closed by providing either integration or voluntary retirement with a rehabilitation package. More than 90 percent of the ex-combatants opted for the voluntary retirement package and rejoined mainstream society. The process was completed by integrating 1,422 ex-combatants into the Nepali army and reintegrating 15,630 people back into society (NIPS 2013). Immediately after closure of the cantonments, a strange phenomenon was observed as a significant number of the ex-combatants decided to live near their previous cantonments. When asked, they claimed that there were better facilities and livelihood options than in the natal villages. This may also be, albeit uncorroborated, due to the possibility of social stigma and discrimination in their respective villages, as some accounts of ex-combatants being unwelcome in their natal villages have been recorded.

Generally, the resettlement of ex-combatants into new places raised many new questions, and access to resources remained a serious concern. Similarly, the issues of dignity and collaboration among and between the community people and ex-combatants and entering the preexisting social structure and exclusion on the basis of caste, class, and gender created some problems in terms of social reintegration for the ex-combatants. This occurred as many were attracted to the Maoist Party to fundamentally transform and dismantle the existing forms of discrimination in society and create better economic opportunities to secure their futures (Thapa and Sijapati 2004).

This was the reason most of them fought and joined the war on the Maoist side, and the prospect of being reintegrated back into the same forms of discrimination and limited economic opportunities that they actively fought was 
highly problematic.

In all post-conflict countries, the primary goal of disarmament, demobilization, and reintegration of the former belligerents and security sector reform is to ensure security and stability in post-conflict environments to nurture recovery and development (Bhatt 2016, 354). Similar expectations arose in the process of supervision, integration, and rehabilitation of ex-combatants in Nepal. In this context small scale preliminary research of ex-combatants absorbed into communities was conducted between August 2012 and August 2013. Pro Public carried out a baseline survey in thirteen communities absorbing ex-combatants in selected communities of Sunsari and Saptari in the east; Makawanpur in the central; Nawalparasi, Rupandehi, and Kapilbastu, in the west; Dang, Surkhet, Banke, and Bardiya in the mid-west; and Kailali in the far west. This study was designed to help understand the immediate impact of social reintegration of ex-combatants into local communities. The report was instrumental at the programmatic level of the non-governmental sector by highlighting the existing situation of ex-combatants in communities, and helped to develop a deeper understanding of the actual experiences of ex-combatants entering into new settlements.

The study was eye-opening as it provided an understanding of the complexities and challenges that ex-combatants faced in their respective communities after they returned to their families. Furthermore, the report was very useful in terms of exploring the strengths, weaknesses, opportunities, and potential threats from the community members and the ex-combatants experiences. The research strongly suggests that the reality of social reintegration was significantly different than the expectations raised during the war and cantonment life.

The narratives gathered from foot soldiers and senior commanders, men and women, and so on, indicate that the challenges faced by the ex-combatants were very diverse. The problems among the various categories of ex-combatants were also different from the ones that chose integration into the Nepal Army and opted for rehabilitation. In the initial phase of reintegration, many ex-combatants suffered from their past identity as "ladaku" (combatants) and providing for their basic needs (buying property, building homes and a family, and securing livelihoods) in their new communities (Chautari 2013, 5).

They faced further difficulties in terms of obtaining adequate packages to build a better life, such as better access to healthcare, education for their children, and a dignified and secure life-socially, economically, and politically. Additionally, addressing gender issues became a major concern for the Maoists, since a significant number of women were mobilized as combatants during the conflict, as women party members participated as active combatants in the Peoples' Liberation Army (Goswami 2015; Bhandari 2016).

When combatants re-settled in new communities, they were perceived 
as former "enemies" by community members, and the ex-combatants saw the community people, those who did not subscribe to Maoist ideas, as "prabiratan birodhi, Samant" (orthodox feudal). That is, both sides somehow managed to look down on one another. A sense of insecurity, fear, alienation, non-cooperation, being denied roles in social and development activities, and a real potential for conflict among the two groups of people were just some of the pertinent issues reported during the assessment (Pro Public 2012). In this context, the initiative "From Combatants to Peacemakers," or "Ladaudekhi Shantinirmata Samma," was designed to support the ex-combatants and other community members. ${ }^{1}$

The first section of the article examines the initiative of dialogue as a pioneering approach in terms of promoting social harmony and peace in communities absorbing the ex-combatants. The second section deals with the seven step dialogue process, and the third section analyzes how effective a social dialogue group is in transforming the "enemy" into a friend. Finally, all major arguments of the article are discussed and analyzed in detail to determine the overall effectiveness of the initiative on individuals and communities affected by the reintegration process.

\section{From Combatants to Peacemakers Initiative}

The "From Combatants to Peacemakers" program was designed by a civil society organization as a unique initiative to facilitate the social reintegration of excombatants into local communities in Nepal, with the primary goal of achieving social harmony and peace. The project took place from the October 1, 2015 until May 31, 2017 (with no funding extension), and was implemented by Pro Public, a civil society organization in Nepal with more than twenty-five years of experience in governance, human rights, litigation, and peacebuilding, with the support of USAID as stipulated in USAID's Annual Program Statement (APS) for Conflict Mitigation and Reconciliation Programs and Activities in Nepal (USAID Nepal 2015).

In order to facilitate social reintegration and promotion of peace at the community level, Pro Public hypothesized that the existing gaps between excombatants and host communities would be greatly reduced by social dialogue activities. The program formed social dialogue groups and community mediation centers, promoted and strengthened the relationships and trust between the excombatants and community members through peace activities, and contributed to bridging the existing gender, caste, and ethnic divides through empowering ex-combatants, community people, and representatives from local government bodies (Pro Public 2015). The activities were designed to foster social harmony and reconciliation as well as mitigate possible conflicts in their communities. Dialogue and mediation are ways to facilitate the social integration of ex- 
Figure 1. From Combatants to Peacemakers

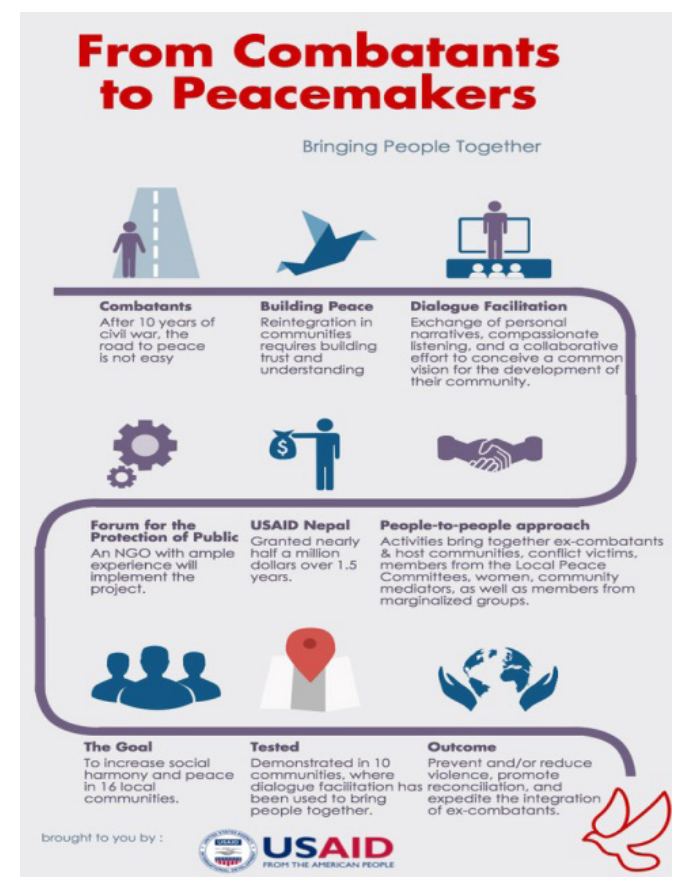

Source: USAID Nepal (2015)

combatants, promote social harmony, and support and facilitate the healing and reconciliation processes in affected communities. Aiming to promote social harmony and peace in sixteen communities that had absorbed ex-Maoist combatants, a number of objectives and actions were proposed and acted upon.

\section{Approaches}

The implementation approach was focused on building the capacity of the main beneficiaries by conducting trainings in dialogue facilitation and mediation. Capacity-building was directly linked to community engagement and activities, specifically dialogue facilitation, peace events, and community envisioning with local stakeholders, and mediated by the dialogue facilitators.

With reference to the idea of the role of three different levels of leadership in any conflict developed by Lederach (1997), grassroots actors' engagement in peacebuilding was designed in customized ways. The role of combatants along with local leaders of NGOs, such as people working as community developers, local peace committees, traditional leaders, and local government officials, was also considered in the project design. 
The goal of achieving peace at the grassroots level was the main objective by providing training for ex-combatants and host community members in dialogue facilitation and mediation, and by supporting them in initiating and facilitating social dialogue between different social groups in their communities. At the broader level, it was aimed at preventing/reducing violence, promoting reconciliation, and expediting the social integration of ex-combatants into the communities where they were residing. ${ }^{2}$

The framework of contribution, or the model intervention, was a peopleto-people approach in which all activities were designed to bring together excombatants and host communities, conflict victims, local peace committee members, women, and community mediators, as well as marginalized groups (USAID 2015). ${ }^{3}$ The dialogue facilitators focused on building trust and understanding between the participants by encouraging the sharing of personal narratives, compassionate listening, and the creation of a common vision for the development of their respective communities. They mediated conflicts in the community upon request and provided para-psychosocial counseling services to anyone in need. The assumption was that when adequate dialogue facilitation and mediation services were provided by mixed dialogue teams in the communities, and the communities made use of these services, violence was prevented and/ or reduced, reconciliation was promoted, and the integration of ex-combatants expedited (ibid.). This led to increased peace and social harmony in the communities.

\section{Dialogue}

In general, dialogue is a conversation for the purpose of revealing common sense and mutual acceptance and consideration as well as a process of interaction in which people listen to each other deeply. The term dialogue in relation to conflict is often generalized and used interchangeably with discussion, negotiation, and general political discourse (Feller and Ryan 2012). The understanding of dialogue varies from analyst to analyst and practitioner to practitioner. One of the challenges in terms of adequately defining dialogue in relation to conflict is that scholars and practitioners present a wide range of processes and projects as conflict related works (ibid.). Dialogue as an approach to conflict management and peacebuilding is being commonly used in various post-conflict countries in Asia, Europe, Africa, and Latin America. In many countries, a process of dialogue has proven effective not only at bringing about post-conflict resolution but also at addressing transnational issues in war-torn societies. ${ }^{4}$

Dialogue as a component or tool for the social reintegration of excombatants contains some essential components of dialogues practiced in other parts of the world; however, it was evolved in Nepal based on grounded methods through the practice of joint brainstorming sessions between the ex-combatants, community members, and representatives from civil society organizations. At the 
beginning in 2012, Pro Public created a group of potential dialogue facilitators consisting of ex-combatants and community members, including representatives from non-government organizations (NGOs) from various communities where ex-combatants were re-settled after their cantonment life.

Fifteen days of dialogue and collaborative leadership training was conducted by trainers from Inmedio Berlin, a capacity-building organization based in Berlin, between November 2012 and April 2013 (Splinter and Wuestehube 2016, 415). The method was developed by combining the experience gained through the training, input by Pro Public, ex-combatants, and people from the communities, and utilizing the experiences of dialogue in peacebuilding work from other countries, including references to the training provided in 2012-2013 and the experiences of Dirk Splinter and Ljubjana Wuestehube from their work in the former Yugoslavia (Splinter and Wuestehube 2017). It was also inspired by the work of Israeli psychologist Dan Bar-On, who initiated multiple dialogues between survivors of the Holocaust and children of Nazi war criminals, and later between groups of Israelis and Palestinians (Bar-On and Kassem 2004). The finalized method included a combination of dialogue elements-mediation and storytelling in particular. ${ }^{5}$

A similar approach was used in post-genocide Rwanda as socio-therapy. Aiming to redevelop dignity, respect, trust, and safety among the people in Rwanda after the genocide, an intervention of dialogue was made "to assist people in dealing with the negative impacts of the war and genocide, as well as its aftermath, on their daily lives and psychosocial wellbeing, and to contribute to sustainable processes of reconciliation within communities" (Richters et al. 2014).

In addition to the experiences of the trainers from Inmedio, other experiences were accumulated based on the project intervention in four communities under GIZ's programmatic collaboration of Support of Measures to Strengthen the Peace Process Nepal and in another six communities with the support of the Nepal Peace Trust Fund between 2013 and 2015. The organization prepared three different training manuals for eight day (basic), seven day (advanced), and five day (refresher) training courses. These focused on how to deal with conflict in constructive ways and how to facilitate an understanding between different groups through social dialogue and mediation. This also involved collaboration with TPO Nepal, an organization working in psychosocial counseling, on the basic and refresher training courses on psychosocial counseling and how to handle different situations.

Implementation of past projects led to the realization that peace emerges out of a process of overcoming isolation, polarization, prejudice, and stereotypes between and among groups (Pro Public 2015). This involved removing the social barriers to interaction in order to create and strengthen the relationships of trust between the ex-combatants and the communities, but bridging the existing gender, caste, and ethnic divides were also major goals of the project. In order 
to achieve these aims, it was necessary to address issues of injustice, oppression, threats to identify and security, and victimization.

\section{The Steps of Social Dialogue}

Social dialogue is one of the major tools of this initiative, and the steps of dialogue were customized in accordance with the needs of the beneficiaries and categorized into seven steps. The first session of dialogue was initiated with the sharing of childhood stories. Good news in the lives of ex-combatants and community members and immediate associated problems were shared among the team members in the second session. The third step was designed to share painful stories of the participants, and the fourth was based on empathy exercises. The fifth step focused on personal envisioning, and the sixth on the identification of community problems. The final step of dialogue was concerned with community envisioning workshops among a wide range of stakeholders.

Childhood Story Telling: In order to become immersed in the process of getting to know each other, sharing of positive childhood memories was the first step forward. This step evoked feelings of having something in common despite all the differences in their rearing, political identities, past experiences, common beliefs, and so on. This was designed to help both ex-combatants and community members realize that at some point everybody was a child, innocent and free from their multiple identities. This meeting was designed to start with a relaxation exercise focusing on body awareness. Then participants were asked to take a "walk" through their childhood memories and stop at a place where, as a child, they recalled a happy memory that was something exciting for him/her; this aspect was both fun and memorable. Even if participants recalled experiences of severe suffering, a happy moment was common to fellow members. Sharing these stories and childhood memories brought a lot of laughter, as often stories were about love and funny incidents. ${ }^{6}$

Good News and Immediate Problems: After about two weeks, the same group of people met for another round of meetings and entered into the process of getting to know each other better through the topic of "Good News and Immediate Problems." The meeting began with a formal welcome and greetings to the participants, and then a review of the first meeting. Participants were encouraged to share a song or poem as an icebreaker, which helped them share good news in their lives in the period between the first and second meetings. In general, participants were asked to share their problems and empathize with one another. That helped them narrow the distance between each other. Prior to the end of the meeting, a time and place was organized for the next meeting. ${ }^{7}$

Painful Story Sharing: The third meeting was designed based on the fact that 
Table 1. Steps of Social Dialogue

\begin{tabular}{l|l}
\hline \hline \multicolumn{1}{c|}{ Session } & \multicolumn{1}{c}{ Stories } \\
\hline First & Childhood Story \\
\hline Second & Good News in Life and Immediate Problems \\
\hline Third & Painful Story \\
\hline Fourth & Empathy \\
\hline Fifth & Personal Envisioning \\
\hline Sixth & Identification of Community Problems \\
\hline Seventh & Community Envisioning \\
\hline
\end{tabular}

Source: Dialogue facilitation and training manuals developed by Pro Public

the from the first two rounds participants were somehow closer to each other, and they were encouraged to share their individual stories and experiences, particularly the most painful memories from the time of the insurgency, as a crucial step in trust-building, healing, and readiness for reconciliation. For this, a degree of confidence was required and it was maintained by the participants, as this step was considered a crucial phase. Facilitators assessed whether it was likely that the group members have a certain level of openness and whether they are willing to listen each other's stories. Without a proper trust-building process, participants were afraid to share their painful stories and facilitators created a safe and conducive space. The meeting went ahead by creating a picture of their individual stories, which is very common in trauma healing but is rarely used in the dialogue process. This exercise was used because it helped participants focus on their story while sharing. This meeting built trust among the group members through active listening during the sharing of stories by team members and empathy practice among peers. Moreover, it was also a helpful tool to summarize all the points to make it easier to follow the listening process. Even if some participants had heard some of these stories ${ }^{8}$ previously, it helps to create a greater mental distance from the painful narratives. ${ }^{9}$

Empathy Exercise: Fifteen days after the third meeting, the fourth round was organized around the theme of empathy. The main principle of the empathy meeting was to create feelings for other people's experiences and pain, and the other processes of the meeting are similar to the second and third meetings, especially in the opening and closing sessions. The main accomplishment of the meeting was to practice four components of nonviolent communication as defined by Marshall Rosenberg: observation, feeling, needs, and requests (Rosenberg 2003). In this phase of the meeting, participants did the empathy exercises with a peer and the exercise of empathy helped participants to become 
familiar with what motivated a person to do something and what his/her needs are in order to do certain activities.

Personal Envisioning: Following a break of two weeks, a fifth meeting was conducted based on the topic of personal envisioning. This step was aimed at contrasting painful memories with something beautiful to strengthen the bonding process within the group through the exercise of personal envisioning. In this step, facilitators invited all the participants to go through an imaginative journey of their life. Then all the participants returned to the group and shared their future plans; for example, where they see themselves in next five years. After listening to this, all participants responded empathetically and shared their willingness to support each other.

Identification of Community Problems: In the sixth step, participants met in order to identify existing community problems. Facilitators usually supported participants in brainstorming in groups community problems by discussing their current situation regarding education, health, drinking water, employment, irrigation, agriculture, roads/bridges, public transportation, fuel, food, pollution, public crime, and other social and political tensions. Based on the discussion, most of the groups identified three or four major problems and designed plans to solve the issues. The group discussion helped all participants become more aware of the status of community problems and led them to jointly work toward planning solutions.

Community Envisioning Exercise: Meeting seven is a community envisioning exercise. At this meeting, facilitators invited both ex-combatants and community members to envisage their community. This step was similar to the activity in step-five, but in a much broader way. It was more about community rather than limited to individuals. This meeting helped participants explore their positive energy, which in turn is supposed to help the community, and focuses on the trust that was built during group dialogues. These activities consist of joint celebrations, working together on community infrastructure, and other meaningful and productive activities.

\section{Unit of Learning: Places and People}

As an intervention, this initiative was continued for eighteen months in sixteen communities in twelve districts across Nepal, from east to west. One hundred and four trained dialogue facilitators were active in dialogue facilitation and other peace activities, and ninety-four dialogue groups were operationalized. This was a platform to share their stories as a part of "getting to know each other better" 
and "joint planning exercises." Altogether, a total of 750 individuals from various walks of life, of which 50 percent were ex-combatants and conflict victims, including community members took part in the dialogue process. Participant selection was done very scientifically, and the overall ratio of ex-combatants and community members was balanced. There were more females than males (56 percent female).

Diversity among the participants was also balanced to include a diversity of caste and ethnic groups: Brahmin Chhetri 40 percent, Dalit 19 percent, ethnic groups 38 percent, Madheshi 1 percent, Muslim 1 percent, and other 1 percent. In terms of age, participants from a wide range of age groups were included; 12 percent of participants were between of the ages of fifteen to twenty-four, but the majority ( 65 percent) of the participants were from the age group twenty-five to thirty-nine, and only 23 percent of the participants were above the age of forty in the year of 2016 .

\section{Analysis}

In a post-conflict society, some of the fundamental questions for peacebuilding organizations include what is the best mechanism to deal with the wounds of the past? How do you reconcile society after a devastating insurgency? In the case of Nepal, these two questions were valid and still relevant in one way or another. For example, social reintegration of ex-combatants remained an enduring problem in Nepal in the period of 2006 to 2012. Still the issue of formerly discharged and verified late minor recruit (VLMRs) has not been addressed properly. After social reintegration, it was commonly observed that ex-combatants were expected to return to their previous social roles, something they were often reluctant to do. In the early phase of reintegration, it proved difficult for former combatants (both male and female) to reintegrate as the vast majority of ex-combatants decided to settle in other places rather than their places of origin, and often settled somewhere closer to their cantonment (Bhandari 2016, 2017).

Dialogue became instrumental in order to bridge the gap between former combatants and community members and for open collaboration in development activities in their respective communities. The trust that developed between the members of the social dialogue groups and the systematic dialogue facilitation by trained ex-combatants and community members working together is considered a unique and successful impact for community reintegration and promotion of social cohesion.

Creating a safe atmosphere in collaboration with the larger community allowed dialogue facilitators to bring the social dialogues to the community level and was an important task for social harmony and peace. The dialogue process remained successful and enabled individuals to promote humanity by 
using the principle of "forgive and forget" in post-conflict reconciliation. The process of storytelling for trust-building using several activities, such as the joint assessment of community problems during the sixth meeting and the community envisioning exercise in the seventh round, conflict perspective analysis, sharing painful stories and memories, discovering common problems and resources, and joint activity planning for better communities were found to be very unique and powerful tools necessary to bridge the gaps between ex-combatants and community members. ${ }^{10}$

Those who were perceived as "former enemies" in the past based on their association were also reconciled. They are living together and jointly struggling for better lives. In fact, the story telling exercise has proved a supportive tool to reconcile a society. A participant said that "at the beginning dialogue sounds funny, but very powerful weapon to release the painful situation through sharing personal stories in a close circle of people." ${ }^{11}$ Learning skills and sharing stories during different periods of time was one of the components of the program. Most of the participants of social dialogue groups agreed that, "training became instrumental and the relationship between ex-combatants and community members improved significantly" (Pro Public 2017).

The sharing of stories between ex-combatants and community members is considered useful in terms of changing attitudes and perceptions of both the ex-combatants and the community members. Likewise, dialogue helped ex-combatants and community people understand each other better. At the beginning, it was perceived that the program was irrelevant and it was too late to start such an effort in the community. However, when the program was implemented participants realized that this program is quite relevant to their society. Finally, the program was proven not only relevant for ex-combatants and host-communities in the settlement areas of ex-combatants, it was considered equally beneficial to other individuals of various different groups in postconflict regions. A change in attitude has a positive impact on a community trying to restore peace. Interestingly, the program enabled ex-combatants and community members to part-take in a "social work" type approach to their issues and enhanced their cordial relationship, which can be seen through the accommodating exchange of ex-combatants and community members in their new found social and cultural programs within their communities. ${ }^{12}$ In some areas, it was reported that ex-combatants and people from marginalized backgrounds, those who were neglected in the past, are now considered role models in the development projects, such as drinking water projects, forest user groups, and school management committees, etc., led by the government and other development partners. ${ }^{13}$

One of the core philosophies of the dialogue program was to heal past wounds and create an opportunity to share both happiness and pain among the people, and to translate this into practice. Representation is one of the most 
serious concerns in these communities and the dialogue program became one of the gateways for ex-combatants, in most of the communities, to enter into development activities and other social engagements. In addition, enhanced leadership skills and positions were found to be one of the positive aspects that emerged from the program. ${ }^{14}$

The modality of sharing painful stories and past experiences by excombatants and community people helped them to get closer over a short span of time. Also, the collaboration and joint initiatives of ex-combatants and community people in a number of peacebuilding activities helped them to realize the dignity and existence of each other. Apart from the ex-combatants, conflict victims also participated in the social dialogue process, and the victims and those who lost family members demanded support in healthcare, education, vocational skills, livelihood opportunities, and employment. However, this program was limited only to ensuring participation, ownership, capacity-building, and leadership training of ex-combatants, marginalized communities, and community members (ibid.). Yet, the success of the program suggests that extending the initiative to include all community members should perhaps be considered for future interventions.

\section{Conclusion}

An in-depth and more systematic academic study of this initiative is required in the future to accurately understand the long-term impact of a social dialogue initiative in reintegration of ex-combatants and promoting social harmony and cohesion. Programmatic experiences and observations suggest that social dialogue is a successful technique in terms of facilitating social reintegration of ex-combatants and promoting social harmony and peace at the community level. Also, the initiative is effective in building trust between ex-combatants and community members, and it can utilized as an effective tool in other multidimensional conflicts at the community level. Based on the experiences over the eighteen months of this initiative, the author has concluded that the sevenstep dialogue, which was applied to deal with past dimensions of pain and grief through a story-telling approach and group discussion, is effective.

An organized and sequential social dialogue (from childhood stories to community envisioning) is helpful to ex-combatants and community people in transforming their distorted perceptions of enemies into that of friends. Even in the discussion with other stakeholders, the approach of dialogue is widely considered unorthodox and rarely practiced by national and international organizations. In fact, it was extremely successful in reintegrating former Maoist combatants into local communities.

Overall, the initiative is considered a very successful reintegration program, 
especially in the context of Nepal. However, in order to make the dialogue initiative more useful in bridging the gap between conflicting parties in the future, it can be combined with other activities (arts/media) to reach more people. The initiative has proven that social dialogue can be applied to other social and cultural divides in Nepal. Perhaps the current identity based conflicts and ethno-political tensions in Terai would benefit from this initiative. The dialogue initiative could be further linked with the work of transitional justice providing mechanisms, such as the Truth and Reconciliation Commission (TRC) and Commission of Investigation on Enforced Disappeared Persons in Nepal (CIEDP), by designing dialogue between conflict victims and other stakeholders at the grassroots and sub-national level. Also, other peacebuilding initiatives practiced in Nepal could benefit from integrating the elements of storytelling. Finally, being a scholar of conflict and peace studies and gaining the experience in the post-conflict peacebuilding in Nepal, the author strongly believes that other post-conflict countries may utilize this method of social dialogue to bridge the existing gaps between conflicting parties, heal their wounds, and produce reconciliation in other societies.

\section{Acknowledgements}

A draft version of this article was presented at the International Peace Researchers Association Conference in November 2018 in Ahmadabad, India. The generous support received from the IPRA Foundation for conference registration, accommodation, and a travel grant to attend the conference is also appreciated. The author would express sincere thanks and acknowledge the support of the IPRA Foundation. The initial draft of this article was presented at the International Conference on Political Transition, Non Violence and Communication in Conflict Transformation, Pattani, Thailand, January 2426,2017 . The author expresses sincere thanks to the commentators and other participants for their constructive feedback.

Similarly, the author expresses his sincere thanks to Lt. Gen. (Retd.) Bala Nanda Sharma, coordinator at the Secretariat of Special Committee for Supervision, Integration and Rehabilitation of Maoist Army Combatants for his trust, guidance, and mentorship in the work of integration and reintegration. Also I would like to express my sincere thanks to entire team of "From Combatants to Peacemakers" at Pro Public (Senior Advocate and Public Interest Litigation expert Prakash Mani Sharma, Baburam Poudel, Prem B.K, Jagat Sharma, and Mamata Shah) and USAID Nepal's specialists for the project namely Amanda Cats-Baril and Sumitra Manandhar for their constant guidance and encouragement. Last but not least, I would like to express my deepest thanks to the ex-combatants, community members, and authorities from local government bodies for their 
trust, openness, and support of this work.

\section{Notes}

1. This article is based on the author's involvement and experiences as a training, monitoring and evaluation coordinator at Pro Public for the project "From Combatants to Peacemakers Program” between October 2015 to May 2017, as well as author's previous association in the work of supervision, integration, rehabilitation of ex-combatants, and other post-conflict peacebuilding experiences in Nepal (2011 to 2015). In addition to this, the information gathered during the independent research and university's field work at the Department of Conflict, Peace and Development Studies, Tribhuvan University in 2015 and 2018 are also utilized in the article.

2. The project team was stationed in Kathmandu and provided support to the dialogue facilitators through organizing training, regular field visits, participation in the major events, and coaching them, sometimes via telephone phone.

3. For this report, marginalized communities denotes ethnic groups, Dalit, Muslim, Madheshi, and other minority communities, in accordance with the characterization of the Nepal government.

4. Under the umbrella of the Conflict Prevention Programme, collaborative leadership and dialogue (CLD) was one of the new initiatives of UNDP in Nepal for implementing dialogue as a tool of post-conflict peacebuilding among political parties and civil society groups in various regions of Nepal.

5. The initiative is popularly known in Nepal as "From Shared Narratives to Joint Responsibility" (or Sha;re Center) to the ex-combatants and community people. It was initiated with the support of Inmedio Berlin and dialogue sessions were facilitated by trained ex-combatants and community people.

6. During childhood story sharing, most participants in the social dialogue group shared stories of troublemaking and fun including experiences of stealing fruits from others, fun activities in their classroom and at home, and cheating their parents and teachers, etc.

7. In this session, good news stories shared included their children's success in school, husband's job, purchasing land, and involvement in social and political forums. Likewise, current economic hardship, problems of livelihood, inability to send their children to a private school, poor condition of their house, etc. are examples of current life problems.

8. Participants often shared their stories of losing parents, stories of being attacked during the conflict, road accidents, loss of property during the conflict, forceful involvement in war, etc.

9. The guiding question for this session was: "What happened in your or family's life that shaped your view of the other group or your beliefs regarding the Maoist conflict and other conflicts? Please think of one specific incident and draw a picture that captures the painful incident."

10. A female, representing a community, shared her experience: "For me, the perception towards the then Communist Party of Nepal (Maoist) and ex-combatants was negative. I had never thought to be close with them when we experienced the suffering and pain during the time of conflict. When I was invited to participate with ex-combatants in dialogue facilitation and mediation training, my experience itself was different; it was 
uncomfortable to be in same training with ex-combatants. I had a completely negative perception of them due to their past affiliation with the insurgency. Even after their reintegration into the society, I never felt comfortable interacting with them. Later, I joined training and my roommate also happened to be an ex-combatant from my community. I was afraid to talk with ex-combatants in the evening. I slept early while she was watching television, and woke up early in the morning while she was sleeping. I left the room for breakfast without saying a single word to her. Throughout the night, we hardly said one or two words despite being roommates. On the first day of training when I was there with her sharing stories from our childhood, it helped me open up to her. Similar childhood experiences brought us closer to each other."

11. An ex-combatant from Dharan Sunsari during the training in December 2015 shared his opinion: "When I was invited to the eight day basic training, I was not interested in the dialogue program. However, I realized that it is better to participate in training instead of sitting idly at home. We combatants and community members travelled together from our places of residence (Dhran) to the training place (Hetauda) and even my roommate was a fellow community member and affiliated with a different political party. On the first day, I didn't talk much with him. After going through the session of storytelling throughout the eight days of training on dialogue facilitation and mediation, my fellow community member became the closest to my heart. He felt more connected to me than my family members due to active engagement and attention to each other's stories; we laughed together and cried together during the story sharing process."

12. The perception of individuals towards one another was completely changed. Some of the participants of the dialogue program shared that in the first round of training they travelled together from their residence to the training venue, stayed in the same hotel and participated in the same training. Ex-combatants and community people were very fearful of each other at the beginning of the training, and this fear waned with each session of dialogue. Also, the provision of collaboration between ex-combatants and community people in their community as center coordinators in peace libraries made them closer with one to other. Now, they perceived each other as family and being ready to support each other even in difficult situations. In line with this generalization, a participant from Udaypur district realized that step-wise dialogue was not only instrumental in how to share their personal stories to other people, it was equally helpful in changing his personal behavior. He shared his story of transformation from an isolated social character (drug addict) to one of the popular social workers in his town. He added that after he joined the program community, ex-combatants in his area felt he was an asset to community. A dialogue facilitator from Udaypur district, as a representative statement in leadership empowerment, said that "I was neglected from the party. When I joined this program and started to work as a dialogue facilitator in my community, it helped me to interact with the larger community. Right now, I am considered an asset to society and the party itself. I am on the Forrest User Group Committee. Leaders from the Maoist party also are offering me very good positions, which I consider an output of my role in my community."

13. Based on their experience, dialogue facilitators shared that ex-combatants are considered heroes in their society with the skills of dialogue facilitation and mediation.

14. Being a witness of project implementation and monitoring and evaluation, I have observed that a majority of ex-combatants who participated in the program as dialogue facilitators are considered role models in their society for their coordinating skills and 
leadership qualities.

\section{References}

Bar-On, Dan, and Fatma Kassem. 2004. "Storytelling as a Way to Work through Interactable Conflicts: The German-Jewish Experience and Its Relevance to the Palestinian-Israeli Context." Journal of Social Issues 60 (2): 289-306.

Bhandari, Chiranjibi. 2015. "Reintegration of Maoist Ex-Combatants in Nepal." Economic and Political Weekly 50 (9): 63-68.

Bhandari, Chiranjibi. 2016. "Social Realities of War and Peace: Expectation and Realities of Female Ex-Combatants in Nepal." In Nepal Transition to Peace: A Decade of the Comprehensive Peace Accord 2006-2016, eds. Pankaj Adhikari, Subash Ghimire, and Vidyadhar Mallik, 242-259. Kathmandu: Nepal Transition to Peace Initiative (NTTP-I).

Bhandari, Chiranjibi. 2017. "People's Libaration Army Post-2006: Integration, Rehabilitation or Retirement?” In Two Steps Forward, One Step Back: The Nepal Peace Process (Accord Issue 26), eds. Alexander Ramsbothm, and Deepak Thapa, 46-49. London: Conciliation Resources.

Bhatt, Deepak P. 2016. "Nepal's Homegrown Model: Integration and Rehabilitation of Maoist Combatants." In Nepal Transition to Peace: A Decade of the Comprehensive Peace Accord 2006-2016, eds. Pankaj Adhikari, Subash Ghimire, and Vidyadhar Mallik, 354-365. Kathmandu: Nepal Transition to Peace Initiative (NTTP-I).

Chautari, Martin. 2013. "Political Risk and Ex-combatants." Policy Brief No. 9, August. http://himalaya.socanth.cam.ac.uk/collections/journals/mcpb/pdf/MC_ PolicyBrief_09_ENG.pdf (accessed April 19, 2019).

Feller, Amanda, and Kelly Ryan. 2012. "Definition, Necessity, and Nansen: Efficacy of Dialogue in Peacebuilding." Conflict Resolution Quarterly, Special Issue: Colloquy on Dialogue Processes 29 (4): 351-380.

Goswami, Roshmi. 2015. "UNSCR 1325 and Female Ex-Combatants: A Case Study of Maoist Women of Nepal." UN Women, October. http://www.unwomen.org/en/ digital-library/publications/2017/5/unscr-1325-and-female-ex-combatants (accessed April 19, 2019).

Joshi, Madhav, and Subodh R. Pyakurel. "Individual-Level Data on the Victims of Nepal's Civil War, 1996-2006: A New Data Set." International Interactions 41 (3): 601-619.

Lederach, John P. 1997. Building Peace: Sustainable Reconciliation in Divided Societies. Washington D.C.: United States Institute of Peace.

NIPS (Nepal Institute for Policy Studies). 2013. "Nepal's Peace Process: A Brief Overview." Policy Paper, July, Issue 1, Vol.8. https://issat.dcaf.ch/download/111494/2023947/ Nepal's\%20Peace\%20Process_A\%20Brief\%20Overview_Eng\%20(2).pdf (accessed April 19, 2019).

Pro Public. 2012. "Baseline Study: Consultation Processes for Community-Based Integration of Ex-Combatants in Five Pilot Communities." Un-published.

Pro Public. 2015. "Project Document Combatants to Peacemakers (USAID Nepal)." Anamnagar, Kathmandu.

Pro Public. 2017. "Combatants to Peacemakers Program.Annual Report." Kathmandu, 
Nepal. http://propublic.org/wp-content/uploads/A-Report-of-From-Combatants-toPeacemakers.pdf (accessed May 8, 2019).

Richters, Annemiek, Grace Kagoyire, Theophile Sewimfura, and Angela Jansen. 2014. "Rwanda's Mediation of Memorialization through Community-Based Sociotherapy." E-International Relations, July 8. https://www.e-ir.info/2014/07/08/rwandasmediation-of-memorialization-through-community-based-sociotherapy/ (accessed April 19, 2019).

Rosenberg, Marshall. 2003. Nonviolent Communication: A Language of Life (2nd edition). Encinitas, CA: Puddledancer Press.

Simon, Robins, Ram Kumar Bhandari, and The Ex-PLA Research Group. 2016. "Poverty, Stigma and Alienation: Reintegration Challenges of ex-Maoist Combatants in Nepal: A Participatory Action Research Project with Ex-PLA Fighters in Nepal." http://www. simonrobins.com/Robins\%20et\%20al\%20-\%20Reintegration\%20challenges\%20 of\%20ex-Maoist\%20combatants\%20in\%20Nepal.pdf (accessed April 19, 2019).

Splinter, Dirk, and Ljubjana Wuestehube. 2016. "FromShared Narratives to Joint Responsibility." In Nepal Transition to Peace: A Decade of the Comprehensive Peace Accord 2006-2016, eds. Pankaj Adhikari, Subash Ghimire, and Vidyadhar Mallik, 410429. Kathmandu: Nepal Transition to Peace Initiative (NTTP-I).

Splinter, Dirk, and Ljubjana Wuestehube. 2017. "From Shared Truths to Joint Responsibility (Sha: re) - Trainer's Manual. Berlin/Kathmandu (Revised).” https://www.inmedio.de/ sites/default/files/Training\%20Manual\%20Nepal.pdf (accessed May 8, 2019).

Subedi, DB. 2013. "Dealing with Ex-Combatants in a Negotiated Peace Process: Impacts of Transitional Politics on the Disarmament, Demobilization and Reintegration Programme in Nepal." Journal of Asian and African Studies 49 (6): 672-689.

Thapa, Dipak, and Bandita Sijapati. 2004. Kingdom Under Seige: Nepal's Maoist Insurgency, 1996 to 2004. Kathmandu: Zed Books.

UNDP (United Nations Development Programme) Nepal. 2009. "Interim Constitution of Nepal, 2063 (2007)." http://himalaya.socanth.cam.ac.uk/collections/rarebooks/ downloads/Nepal_Interim_Constitution_2007_first_to_sixth_amendements.pdf (accessed May 8, 2019).

UNDP (United Nations Development Programme) Nepal. 2011. "Rehabilitation of ExCombatants in Project document of United Nations Inter-agency Rehabilitation Programme (UNIRP)."

United Nations Peacemaker. 2006. "Comprehensive Peace Accord (CPA).” https:// peacemaker.un.org/nepal-comprehensiveagreement2006 (accessed April 15, 2019).

USAID (United States Agency for International Development) Nepal. 2015. "From Combatants to Peacemakers." Conflict Management and Mitigation Program, USAID Nepal, September 29.

Chiranjibi Bhandari is an Assistant Professor in the Department of Conflict, Peace and Development Studies at Tribhuvan University, Nepal. He also worked as a training, monitoring, and evaluation coordinator for the "From Combatants to Peacemakers" program at Pro Public from October 2015 to May 2017. 